\title{
Comparative biomass of sediment benthos across a depth transect, Chatham Rise, Southwest Pacific Ocean
}

\author{
K. Berkenbusch ${ }^{1, *}$, P. K. Probert ${ }^{1}$, S. D. Nodder $^{2}$ \\ ${ }^{1}$ Portobello Marine Laboratory, Department of Marine Science, University of Otago, Portobello 9014, New Zealand \\ ${ }^{2}$ National Institute of Water and Atmospheric Research (NIWA) Limited, Kilbirnie, Wellington 6021, New Zealand
}

\begin{abstract}
The present study examined the partitioning of carbon between benthic meio- and macrofauna at sites between 350 and $3100 \mathrm{~m}$ water depth across Chatham Rise, Southwest Pacific Ocean. Biomass declined with increasing depth on both sides of the crest, but showed different patterns for each faunal size grouping at the deepest sites. Meiofaunal biomass was highest on the crest and lowest at $2800 \mathrm{~m}$, south of the rise (76 and $8 \mathrm{mg} \mathrm{C} \mathrm{m}^{-2}$, respectively), whereas macrofaunal biomass peaked on the southern slope $\left(1169 \mathrm{mg} \mathrm{C} \mathrm{m}^{-2}\right.$ ), with lowest values at the deep northern sites (88 and $116 \mathrm{mg} \mathrm{C} \mathrm{m}^{-2}$ ). Macrofauna dominated total faunal biomass (>80\%), although the relative importance of meiofauna increased with increasing depth on the northern side. The meiofauna: macrofauna carbon ratio was correspondingly low across all sites (0.04 to 0.10), except at the deep 3100 and $2300 \mathrm{~m}$ northern sites (0.16). These biomass patterns were significantly related to sediment chlorophyll a concentration, indicating greater availability of high-quality (labile) organic carbon. The lack of a shift towards the smaller benthic size class with decreasing food supply at the deep southern site (2800 m depth) appeared to be related to relatively high sediment particulate organic carbon and high calcium carbonate contents, which also influenced meio- and macrofaunal biomass. These findings reveal the close link between faunal biomass and food availability in deep-sea habitats and highlight the importance of phytodetritus in structuring benthic assemblages in the Chatham Rise/Subtropical Front region.
\end{abstract}

KEY WORDS: Metazoan $\cdot$ Sediment characteristics $\cdot$ Phytopigment $\cdot$ Deep sea $\cdot$ Regression models Resale or republication not permitted without written consent of the publisher

\section{INTRODUCTION}

Deep-sea sediments have long been recognised as food-limited habitats, with benthic communities greatly dependent on food supplied from overlying waters (Thiel 1979, Gage \& Tyler 1991, Giere 2009). Pelagic productivity and processes largely determine the quantity and quality of organic matter reaching the seafloor, which can originate from a variety of sources, including phyto- and zooplankton remains, crustacean moults, macro-aggregates ('marine snow'), and faecal pellets (Rowe \& Staresinic 1979, Gooday \& Turley 1990). Sedimentation of photosynthetically produced organic matter can lead to the deposition of relatively undegraded material on the seafloor that is rapidly consumed and/or incorporated into benthic biomass and represents a significant food source for deep-sea benthos (e.g. Richardson \& Young 1987, Pfannkuche 1993, Danovaro et al. 1999, Levin et al. 1999, Blair et al. 1996, Witte et al. 2003a,b, Moodley et al. 2005). In this context, seasonal phytoplankton blooms are considered particularly important as they can result in substantial phytodetritus deposition on the seafloor, representing an important (often episodic) food supply (Billett et al. 1983, Witte et al. 2003b, see reviews by Gooday \& Turley 1990, Beaulieu 2002, Gooday 2002).

As the flux of organic carbon is directly linked to surface-water productivity, the supply of organic matter generally decreases with increasing water depth (Pace et al. 1987, Carney 1989). The diminishing food supply 
is reflected in the decline in abundance and biomass of benthic organisms, which has been documented for deep-sea fauna (i.e. mega-, macro- and meiofauna) and bacteria (Rowe et al. 1982, Shirayama 1983, Pequegnat et al. 1990, Sibuet et al. 1993, Soltwedel 2000, Baguley et al. 2006, 2008, Johnson et al. 2007, Deming \& Carpenter 2008). While biomass decreases with decreasing food supply (and increasing depth), the rate of decline differs amongst benthic size components: larger sized fauna, such as mega- and macrofauna, exhibit a greater rate of biomass decline than meiofauna (and bacteria), so that the latter organisms become increasingly important with depth (Snider et al. 1984, Richardson \& Young 1987, Pequegnat et al. 1990, Rowe et al. 1991, 2008, Danovaro et al. 1999).

Although organic matter input has been identified as one of the main factors controlling benthic biomass in deep-sea environments (Tyler 2003), few studies have directly examined the partitioning of carbon across faunal groupings over a wide depth range based on samples taken at the same time and locations (but see Flach et al. 1999, Galéron et al. 2000). The quantification of biomass of different faunal size classes is necessary to understand how differences in primary productivity affect different components of the benthic community. This information is vital to establish the flow of energy through deep-sea food webs and to develop carbon models (e.g. Rowe et al. 2008), which, in turn, help to improve understanding of the functioning of deep-sea ecosystems.

The aim of the present study was to assess the partitioning of carbon between benthic meio- and macrofauna at different depths across Chatham Rise, New Zealand, Southwest Pacific Ocean, and to determine if these benthic assemblages exhibit a shift towards smaller fauna with increasing water depth as observed elsewhere (Flach et al. 1999, Galéron et al. 2000).

\section{MATERIALS AND METHODS}

Study site. Chatham Rise is a broad, submarine ridge that extends east of South Island, New Zealand. The crest is relatively shallow at 300 to $400 \mathrm{~m}$ water depth, with the northern and southern sides of the rise descending to ca. $3000 \mathrm{~m}$ depth (Mackay et al. 2005). The region is characterised by the Subtropical Front, where warm, nutrient-depleted subtropical waters from the north mix with cold, nutrient-rich subantarctic waters from the south, thereby supporting high biological productivity (Bradford-Grieve et al. 1999, Sutton 2001).

As benthic communities north and south of the crest experience contrasting productivity regimes and organic fluxes (Nodder \& Northcote 2001), sampling sites across the rise provide the opportunity to examine benthic biomass at comparable water depths in potentially different trophic environments.

Sample collection and processing. Samples were collected at 9 sites across Chatham Rise in austral spring 2001 (29 September to 14 October; Table 1, Fig. 1; see also Nodder et al. 2007). Sampling sites were situated along a latitudinal transect at $178^{\circ} 30^{\prime} \mathrm{E}$, at water depths ranging from 350 (crest) to $3100 \mathrm{~m}$ north and $2800 \mathrm{~m}$ south of the rise (Table 1). Sediment and infaunal samples were obtained using a multicorer (Ocean Instruments MC-800, $10 \mathrm{~cm}$ diameter cores), with several deployments at each site.

Meiofaunal subsamples $\left(5.3 \mathrm{~cm}^{2}\right.$ syringe cores, $5 \mathrm{~cm}$ sediment depth) were obtained from a single core from each of 3 separate multicorer deployments per site. Samples were preserved in $10 \%$ buffered formalin containing Rose Bengal and subsequently sieved on a $45 \mu \mathrm{m}$ mesh. Meiofauna was extracted by Ludox flotation before being mounted on microscope slides (Somerfield \& Warwick 1996). Using a compound microscope connected to a video image system (Olympus BX51, Soft Imaging System 2007), meiofauna was sorted into main metazoan taxonomic groups and enumerated. Specimen dimensions (maximum length and width) were measured via video image analysis (see Grove et al. 2006) and converted to body volume using standard conversion factors for each taxon (Feller \& Warwick 1988). When nematodes were highly abundant, a random subsample of 50 individuals was measured, and total volume was estimated by multiplying the volume of the subsample by the ratio of numbers counted to the numbers measured (see Grove et al. 2006). Body volumes were converted to biomass by assuming a specific gravity of 1.13 and a carbon:wet weight ratio of 0.1 (Feller \& Warwick 1988).

Macrofaunal samples were obtained from several cores (generally 6 to 8) per multicorer deployment, based on 3 deployments site ${ }^{-1}$. Cores were sieved on a $500 \mu \mathrm{m}$ mesh, either as a whole or by sediment depth sections of $0-1,1-5,5-10,10-15 \mathrm{~cm}$ ), and preserved in $10 \%$ buffered formalin containing Rose Bengal. Macrofauna was sorted into the main taxonomic groups, excluding meiobenthic taxa, i.e. nematodes, harpacticoid copepods, or ostracods. Blotted wet weight was recorded for each taxon (accuracy $0.01 \mathrm{mg}$ ) and converted to carbon biomass using conversion factors for each group following Rowe (1983). Data from cores were combined for each multicorer deployment for subsequent analysis.

Sediment cores (different to those sampled for benthic fauna, 1 core site $^{-1}$ ) were divided vertically into 11 sections $(0.5 \mathrm{~cm}$ sections from $0-5 \mathrm{~cm}$ sediment depth, and one $1.0 \mathrm{~cm}$ section at either $8-9$ or $9-10 \mathrm{~cm}$ sediment depth). Each section was analysed for sediment grain size, total organic matter (TOM), carbonate 


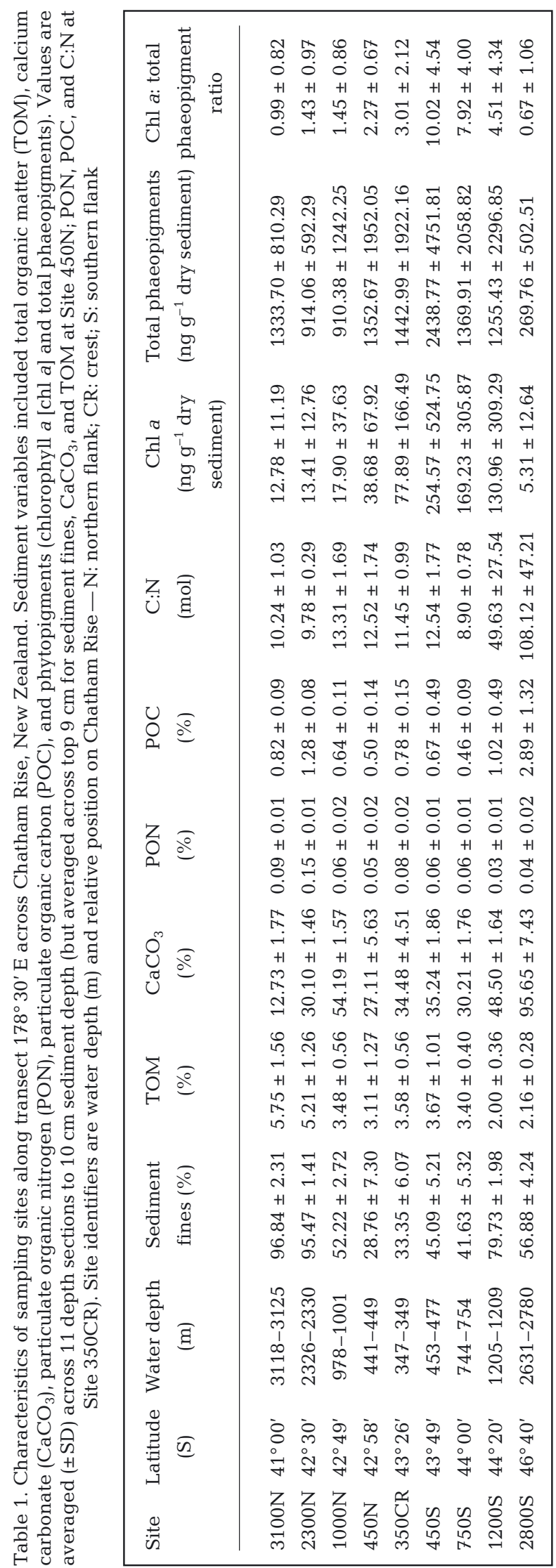

$\left(\mathrm{CaCO}_{3}\right)$, particulate organic carbon (POC), and particulate organic nitrogen (PON) contents as well as molar $\mathrm{C}: \mathrm{N}$ ratio. Sediment grain size was determined by drying subsamples to constant weight and then using a combination of dry-sieving (63 to $500 \mu \mathrm{m}$ - percentage sand) and Sedigraph techniques (<63 $\mu \mathrm{m}$ fractionpercentage silt and clay) (Singer et al. 1988, Bale \& Kenny 2005). Percentage TOM was established by loss-on-ignition $\left(500^{\circ} \mathrm{C}\right.$ for $\left.4 \mathrm{~h}\right)$ (Bale \& Kenny, 2005), and the calcium carbonate contents, by $\mathrm{CO}_{2}$ vacuumgasometric method ( $\pm 1 \%$ accuracy) (Jones \& Kaiteris 1983). POC and PON contents were analysed in dried, acidified (8\% v/v sulphurous acid) sediment samples via a carbon-hydrogen-nitrogen (CHN) analyser (CE Instruments NC2500; precision ca. 2\%) (Bale \& Kenny 2005). Phytopigment concentrations, i.e. chlorophyll a (chl a) and total phaeopigments, including the degradation products phaeophytin and phaeophorbide, were determined in sediment cores sliced vertically into 10 depth sections: surface scrape $(0$ to $0.1 \mathrm{~cm}), 0.5$, and $1 \mathrm{~cm}$ sections to $5 \mathrm{~cm}$ sediment depth, and $2.5 \mathrm{~cm}$ sections to $15 \mathrm{~cm}$, with freeze-dried sediment from each section analysed via high-performance liquid chromatography (Jeffrey et al. 1997).

Data analysis. Differences in meio- and macrofaunal biomass (wet weight and organic carbon) across sites were tested using 1-way ANOVA, after assessing normality and homogeneity of variance (Shapiro-Wilks and Levene's tests, respectively; Zar 1984). When necessary, data were $\log _{10}$-transformed to meet requirements of parametric tests, although transformation did not achieve normality of macrofaunal wet weight and carbon data. Nevertheless, macrofaunal data were tested using this analysis, as ANOVA is relatively robust to non-normality (Underwood 1997).

The influence of sediment parameters on meiofaunal and macrofaunal biomass (organic carbon) and on the ratio between meiofaunal and macrofaunal carbon were analysed using multiple regressions with the following predictors (independent variables): sediment grain size, \% TOM, \% $\mathrm{CaCO}_{3}, \% \mathrm{POC}, \% \mathrm{PON}$, chl a, total phaeopigment concentrations, and chl a:total phaeopigment ratio. Water depth was not included as a predictor variable to avoid collinearity. A maximum of 3 predictors was included in each regression model to ensure that the number of observations sufficiently exceeded that of predictors (i.e. 6- to 10-fold; Quinn \& Keough 2002). As a consequence, all possible combinations of predictors were tested to obtain a regression model that had the highest significant coefficient of determination $\left(\mathrm{r}^{2}\right)$. For significant relationships, partial regression plots (graphing the residuals) were used to illustrate the nature of the relationship between each biomass variable and individual predictors. These residual plots were also used as diagnostic tools to assess 


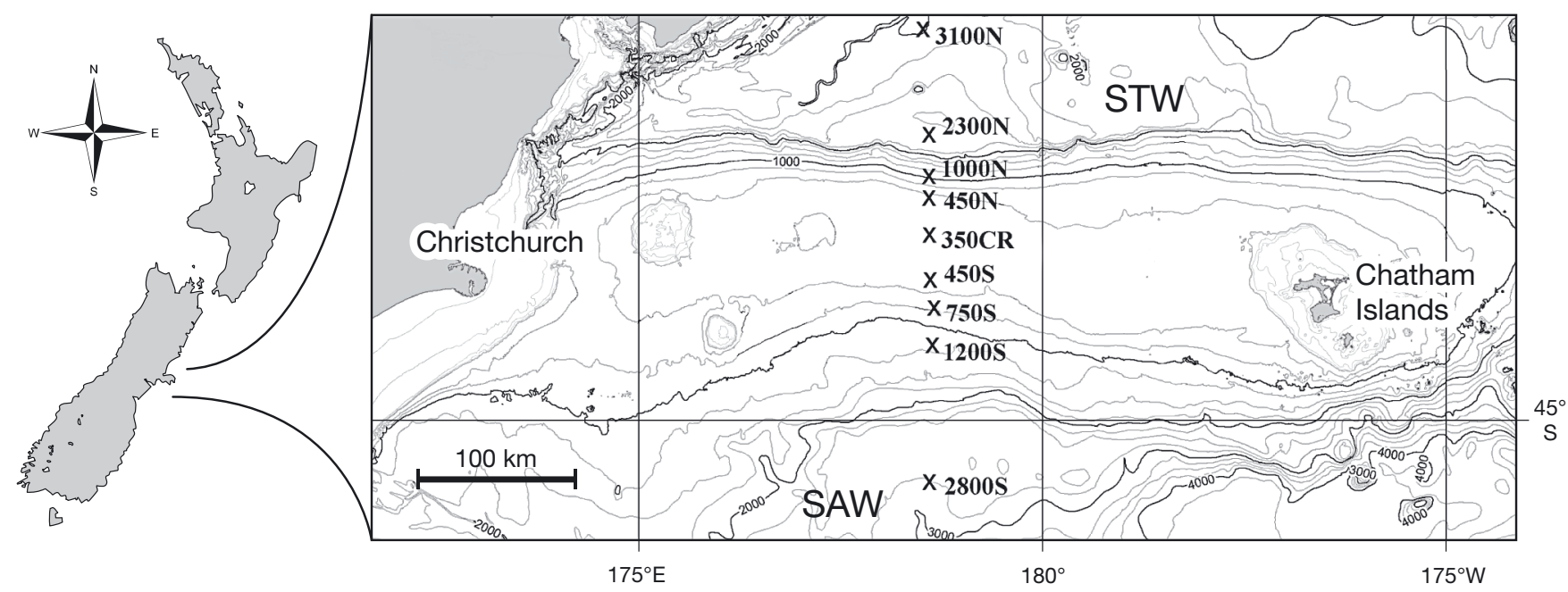

Fig. 1. Deep-sea benthos study sites across Chatham Rise, New Zealand, Southwest Pacific Ocean. Site identifiers: water depth (m) and relative position on Chatham Rise (N: northern flank; CR: crest; S: southern flank). Associated surface water masses that mix in the Chatham Rise region include subtropical water (STW) and subantarctic water (SAW)

that assumptions of linear regression were met. Normality, presence of outliers, and homogeneity of variance were assessed visually using the residual graphs, and collinearity was assessed by examining tolerance and condition index values; Cook's distance and leverage values were used to determine potential outliers (Quinn \& Keough 2002). All data were $\log _{10^{-}}$ transformed.

\section{RESULTS}

\section{Sediment variables}

Sediment parameters showed some variability in relation to water depth and/or position relative to the Chatham Rise crest, with differences particularly evident at the deep sites (>1000 m water depth) on either side of the rise (Table 1). These deep sites were characterised by a high percentage of sediment fines, which was particularly pronounced on the northern side, where sediment consisted of $>95 \%$ fines, while also containing a relatively high proportion of TOM (ca. 5 to $6 \%$ ). In contrast, TOM content was low at the deep southern sites (ca. $2 \%$ ), whereas $\% \mathrm{CaCO}_{3}$ was high, especially at $2800 \mathrm{~S}(>95 \%)$. Sediment \%PON and $\%$ POC were relatively high at deep sites (ca. 1 to $2 \%$ ), with \%PON elevated on the northern side, but \% POC was considerably higher at $2800 \mathrm{~S}$ (ca. $3 \%$ cf. $<1 \%$ at $3100 \mathrm{~N}$ ). At this site (and 1200S), the C:N molar ratio was also particularly high $(\geq 50)$, indicating highly refractory organic matter, while it was markedly lower at deep northern sites (10 to 13). Sediment chl a concentration was highest at $450 \mathrm{~S}$, with high values also at the other shallow southern sites (130 to $255 \mathrm{ng}$ chl a g ${ }^{-1}$ dry sediment), but substantially lower concentrations at 350CR and all northern sites (12 to $78 \mathrm{ng}$ chl a g ${ }^{-1}$ dry sediment), and a drastic decline at 2800S (5 $\mathrm{ng} \mathrm{chl} \mathrm{a} \mathrm{g}^{-1}$ dry sediment). Total phaeopigment concentrations showed a similar pattern on the southern side, but with high values also at all northern sites, although without a substantial decrease with increasing water depth from $350 \mathrm{CR}$ to $3100 \mathrm{~N}$. The chl a:total phaeopigment ratios corresponded closely with chl a concentrations across sites, indicating the availability of relatively undegraded pigmented organic material at shallow sites. There was considerable variability within cores across sediment depth $(0$ to $10 \mathrm{~cm}$ ) owing to extremely high values in surface sediments (see Nodder et al. 2007) and markedly lower values with increasing sediment depth, resulting in large variability in the depthintegrated data (Table 1).

\section{Meio- and macrofaunal biomass}

Meiofaunal biomass (wet weight) showed a clear pattern across Chatham Rise, ranging from $0.6288 \mathrm{mg}$ $10 \mathrm{~cm}^{-2}$ at the shallowest site (350CR) to a minimum of $0.0682 \mathrm{mg} 10 \mathrm{~cm}^{-2}$ at $2800 \mathrm{~S}$. There was a considerable decrease in biomass with increasing water depth on either side of the rise (Fig. 2A), but this trend was more pronounced on the northern side, with higher biomass values on the southern side. Values at $750 \mathrm{~S}$ and $1200 \mathrm{~S}$ were similar to those at $450 \mathrm{~N}\left(0.4\right.$ to $\left.0.5 \mathrm{mg} 10 \mathrm{~cm}^{-2}\right)$, with lowest values at $2800 \mathrm{~S}\left(<0.1 \mathrm{mg} 10 \mathrm{~cm}^{-2}\right)$. There was considerable within-site variability on the crest at $350 \mathrm{CR}$, owing to large differences in polychaete 

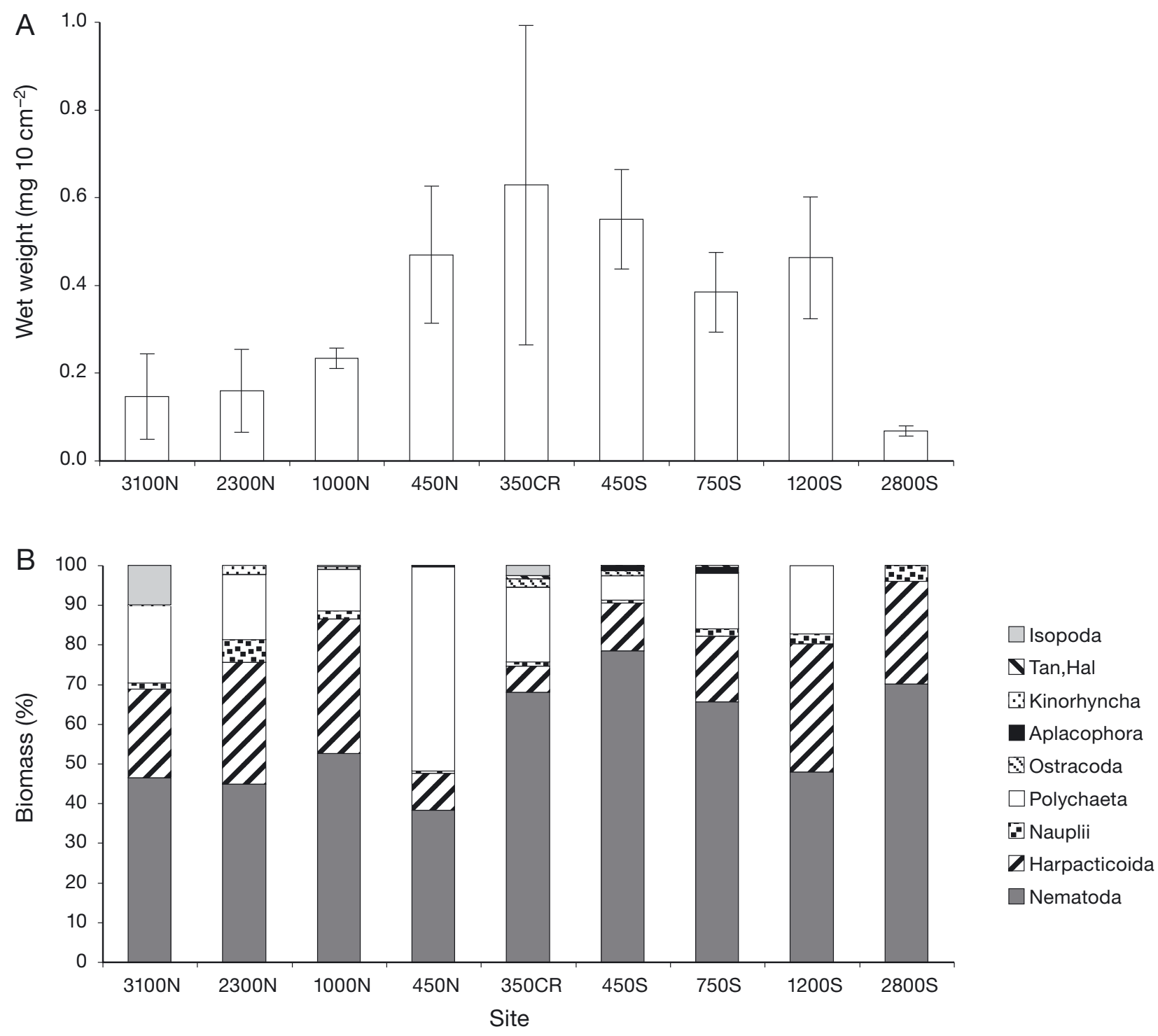

Fig. 2. Meiofaunal biomass (wet weight, $\mathrm{mg} 10 \mathrm{~cm}^{-2}$; average $\pm 1 \mathrm{SD}, \mathrm{n}=3$ ) and contribution of different taxa to total biomass across Chatham Rise, New Zealand. Site identifiers: water depth $(\mathrm{m})$ and relative position on Chatham Rise (N: northern flank; CR: crest; S: southern flank). Tan,Hal: Tanaidacea and Halacaridae combined

biomass among replicate samples at this site (data not shown). Meiofaunal biomass differed significantly across sites (1-way ANOVA, $F_{8,18}=5.173$, p < 0.005); it was significantly lower at $3100 \mathrm{~N}$ than at $450 \mathrm{~S}$, and at 2800S compared with each of the shallow sites $(450 \mathrm{~N}$ to 450S) (post hoc Tukey test, $\mathrm{p}<0.05$ ).

Nematodes consistently dominated total meiofaunal biomass (ca. 45 to $78 \%$ ), and combined with harpacticoid copepods and nauplii, constituted ca. 48 to $97 \%$ of the meiofaunal biomass across all sites (Fig. 2B). The contribution of these meiofaunal groups was lowest at $450 \mathrm{~N}$, where polychaetes accounted for a substantial proportion of overall biomass (ca. 51\%). Polychaete biomass varied at the other sites (between 6.05 and $19.44 \%$ ), and polychaetes were absent at 2800S. Other faunal groups made only relatively minor contributions to total biomass and included ostracods (absent at sites $>1000$ m water depth, 0.09 to $2.10 \%$ at shallower sites), kinorhynchs $(0.01$ to $2.18 \%$, absent at $2800 \mathrm{~S})$, aplacophorans (only at $450 \mathrm{~S}$ and $750 \mathrm{~S}, 1.00$ and $1.53 \%$, respectively), tanaidaceans and halacarids (combined 0.20 to $0.66 \%$, only at $350 \mathrm{CR}$ to $750 \mathrm{~S}$ ), and isopods (only at $3100 \mathrm{~N}$ and $350 \mathrm{CR}, 2.65$ and $9.99 \%$, respectively) (Fig. 2B).

Macrofaunal biomass (wet weight) also showed a depth-related pattern across the rise, with similar, high values at shallow sites, $1000 \mathrm{~N}$ to $1200 \mathrm{~S}$ (13427 to $26791 \mathrm{mg} \mathrm{m}^{-2}$ ) and highest biomass at 750S (Fig. 3A). Lowest biomass values were at $3100 \mathrm{~N}$ and $2300 \mathrm{~N}$ $\left(<2500 \mathrm{mg} \mathrm{m}^{-2}\right)$, where biomass was considerably 
lower than at the deepest southern site, 2800S (ca. $7400 \mathrm{mg} \mathrm{m}^{-2}$ ). Differences in macrofaunal biomass were statistically significant (1-way ANOVA, $\log _{10^{-}}$ transformed data, $\left.F_{8,18}=30.70, \mathrm{p}<0.001\right)$, with values significantly lower at $3100 \mathrm{~N}$ and $2300 \mathrm{~N}$ than that at any other site. Biomass at 2800S was significantly lower compared with $350 \mathrm{CR}$ and the 2 shallow southern sites, 450S and 750S (post hoc Tukey test, $\mathrm{p}<0.05$ ).

Polychaetes generally dominated macrofaunal biomass, constituting 36.99 to $76.45 \%$ of the total. Other taxa made relatively large contributions (>10\%) at some sites, but were absent or contributed little to biomass at others (Fig. 3B). For example, ophiuroids contributed $31.27 \%$ of the total biomass at $1200 \mathrm{~S}$, but accounted for only 0.95 to $9.24 \%$ of total biomass at all other sites; similarly, echinoids accounted for 20.08 and
$11.00 \%$ of biomass at $1000 \mathrm{~N}$ and $750 \mathrm{~S}$, respectively, but were absent at the deepest northern and southern sites ( $\geq 1200 \mathrm{~m}$ depth) and at low proportions (0.19 to $5.80 \%)$ at the shallow sites. Different crustacean groups, including amphipods, isopods, tanaidaceans, and cumaceans, were present at most sites, but generally at low biomass, except at $3100 \mathrm{~N}$, where amphipods accounted for $11.50 \%$. Other minor contributors to biomass were holothurians ( 0.10 to $1.38 \%$ at $1000 \mathrm{~N}$, $350 \mathrm{CR}, 1200 \mathrm{~S}$ ), bivalves (all sites, except 2800S, 3.27 to $6.89 \%$ ), gastropods (absent at several sites, 0.11 to $2.90 \%$ at others), and aplacophorans, sipunculans, and mysidaceans (absent at 2800S, combined 0.05 to $1.30 \%$ at other sites); anthozoans were present only at $450 \mathrm{~S}(4.40 \%)$. Biomass that could not be assigned to a specific taxonomic group was included under 'miscel-
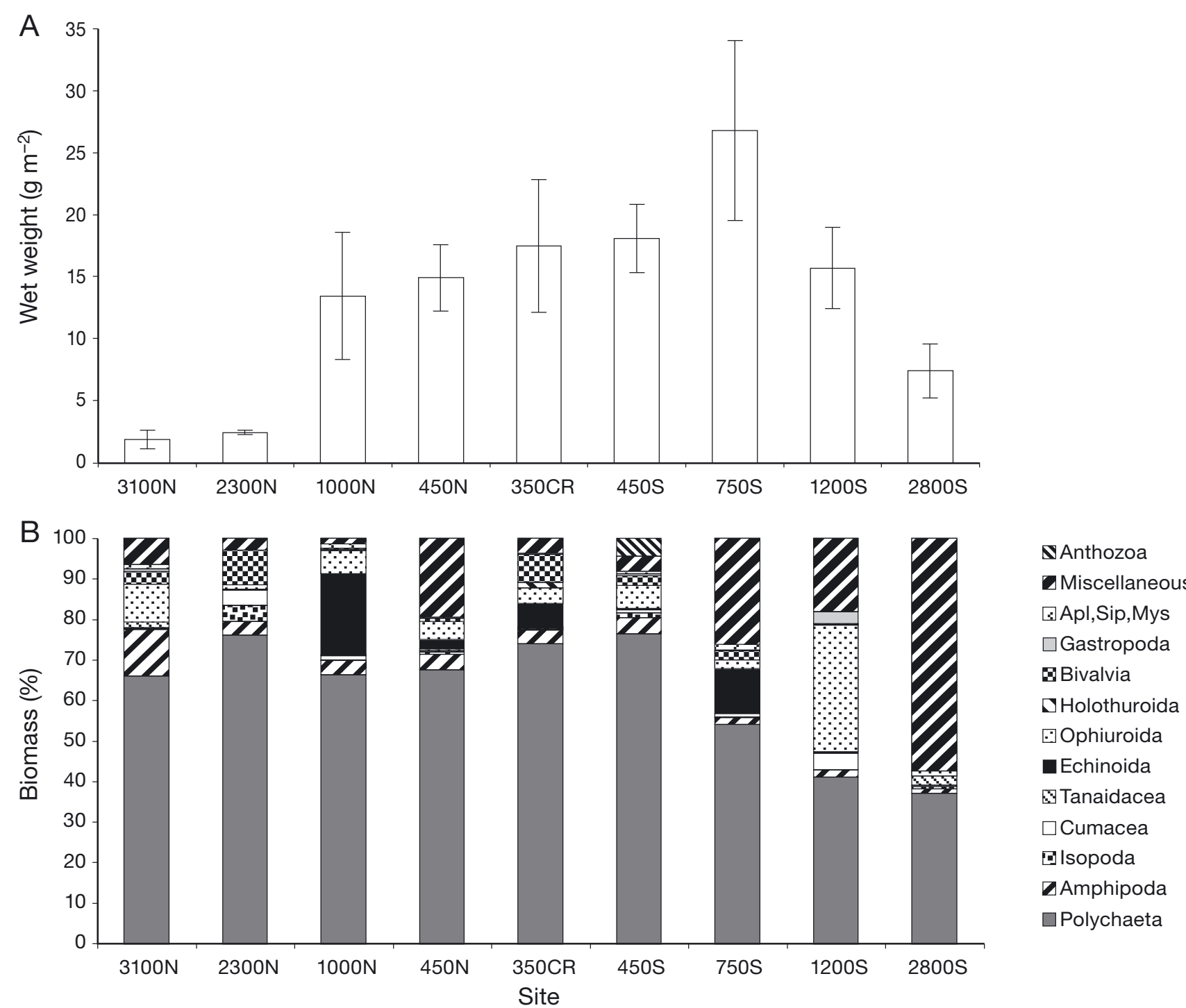

Fig. 3. Macrofaunal biomass (wet weight, $\mathrm{g} \mathrm{m}^{-2}$; average $\pm 1 \mathrm{SD}, \mathrm{n}=3$ ) and contribution of different taxa to total biomass across Chatham Rise, New Zealand (site identifiers: water depth $[\mathrm{m}]$ and relative position on Chatham Rise $-\mathrm{N}$ : northern flank; CR: crest; S: southern flank). Apl,Sip,Mys: Aplacophora, Sipuncula and Mysidacea combined 
laneous' (e.g. body parts such as crustacean antennae that could not be assigned to amphi- or isopods). At most sites, this category was $<10 \%$, but, at 2800 , it constituted $57.49 \%$ of total biomass.

\section{Carbon values}

Meio- and macrofaunal organic carbon values (mg C $\mathrm{m}^{-2}$ ) reflected the wet weight patterns across the rise (Table 2). The highest meiofaunal carbon value was at $350 \mathrm{CR}$, the lowest at $2800 \mathrm{~S}$, and the greatest drop in value was on the southern side between $1200 \mathrm{~S}$ and 2800S. Macrofaunal carbon was highest at 750S, lowest at $3100 \mathrm{~N}$, and showed the greatest decline on the northern side, between $1000 \mathrm{~N}$ and $2300 \mathrm{~N}$. Total carbon, for both faunal groups combined, followed the macrofaunal carbon trend, as macrofauna contributed on average from 83.78 to $97.47 \%$ to total faunal carbon. The meiofaunal contribution was highest at the 2 deepest northern sites, where it constituted around $15 \%$ (Table 2).

Accordingly, the ratio of meio- to macrofaunal carbon biomass was highest at the 2 northern deep sites (0.16), where meiofauna made the largest contribution to overall biomass (Fig. 4). At all other sites, the relative importance of meiofauna was similarly low, and ratio values were at a minimum at $750 \mathrm{~S}$ and $2800 \mathrm{~S}$ (0.04 and 0.03, respectively).

\section{Biomass in relation to sediment variables}

Multiple regressions revealed significant relationships between faunal carbon values and sediment parameters (i.e. sediment chl a) across the Chatham Rise (Table 3, Fig. 5). Meiofaunal carbon was significantly related to sediment chl $a$ and \% POC $\left(\mathrm{r}^{2}=0.702\right.$, $\mathrm{p}<0.001$ ) and increased with increasing chl a concentration, but decreased with increasing \%POC. Macro-

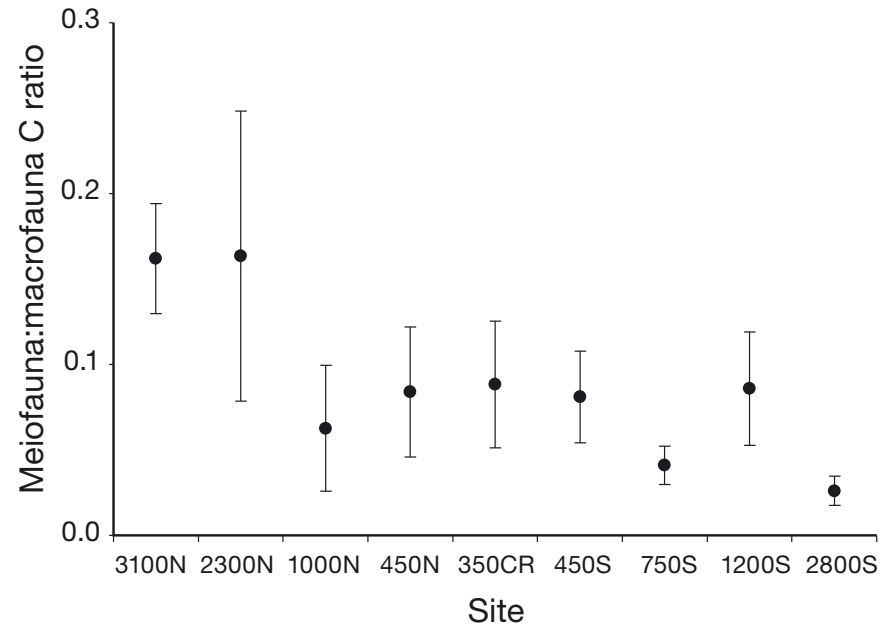

Fig. 4. Ratio of meio- to macrofaunal carbon biomass (mean \pm $1 \mathrm{SD}, \mathrm{n}=3$ ) across Chatham Rise, New Zealand. Site identifiers: water depth $(\mathrm{m})$ and relative position on Chatham Rise (N: northern flank; CR: crest; S: southern flank)

faunal carbon significantly increased with increasing sediment chl a concentration and increasing $\% \mathrm{CaCO}_{3}$ $\left(\mathrm{r}^{2}=0.702, \mathrm{p}<0.001\right)$. The meio- to macrofauna carbon ratio was significantly related to sediment chl $a$ and $\% \mathrm{CaCO}_{3}\left(\mathrm{r}^{2}=0.400, \mathrm{p}<0.005\right)$, with a significant decrease with increasing $\% \mathrm{CaCO}_{3}$ (Table 3, Fig. 5).

\section{DISCUSSION}

Both meio- and macrofauna exhibited assemblage compositions that are consistent with those previously reported from this region and elsewhere. Meiofauna samples are generally dominated by nematodes, followed by harpacticoid copepods, and nauplii (Vanaverbeke et al. 1997, Soltwedel 2000, Vanhove et al. 2004, Gambi \& Danovaro 2006, Grove et al. 2006, Baguley et al. 2008), whereas polychaetes are frequently the most prevalent macrofaunal taxon (Brown

Table 2. Meio-, macrofaunal, and total biomass $\left(\mathrm{C}, \mathrm{mg} \mathrm{m}^{-2}\right)$ and contribution of each faunal grouping to total $\mathrm{C}$ in benthic samples at different sites across Chatham Rise, New Zealand. Site identifiers: water depth $(\mathrm{m})$ and relative position on Chatham Rise (N: northern flank; CR: crest; S: southern flank)

\begin{tabular}{|lcccrc|}
\hline Site & Meiofauna & Macrofauna & Total C & Meiofauna (\%) & Macrofauna (\%) \\
\hline $3100 \mathrm{~N}$ & $17.59 \pm 11.57$ & $87.57 \pm 34.24$ & $105.16 \pm 42.78$ & $16.22 \pm 5.65$ & $83.78 \pm 5.65$ \\
$2300 \mathrm{~N}$ & $19.40 \pm 11.62$ & $115.65 \pm 9.50$ & $135.05 \pm 7.74$ & $14.21 \pm 7.90$ & $85.79 \pm 7.90$ \\
$1000 \mathrm{~N}$ & $28.15 \pm 2.97$ & $557.73 \pm 296.14$ & $585.89 \pm 293.90$ & $5.81 \pm 3.24$ & $94.19 \pm 3.24$ \\
$450 \mathrm{~N}$ & $55.95 \pm 17.78$ & $702.53 \pm 123.12$ & $758.47 \pm 105.63$ & $7.67 \pm 3.25$ & $92.33 \pm 3.25$ \\
$350 \mathrm{CR}$ & $75.98 \pm 44.01$ & $802.64 \pm 208.82$ & $878.62 \pm 194.98$ & $9.22 \pm 6.14$ & $90.78 \pm 6.14$ \\
$450 \mathrm{~S}$ & $66.87 \pm 13.70$ & $854.98 \pm 129.64$ & $921.85 \pm 115.96$ & $7.45 \pm 2.31$ & $92.55 \pm 2.31$ \\
$750 \mathrm{~S}$ & $46.29 \pm 10.74$ & $1168.58 \pm 309.72$ & $1214.87 \pm 312.33$ & $3.92 \pm 1.04$ & $96.08 \pm 1.04$ \\
$1200 \mathrm{~S}$ & $55.73 \pm 16.58$ & $663.46 \pm 78.06$ & $719.19 \pm 71.79$ & $7.85 \pm 2.79$ & $92.15 \pm 2.79$ \\
$2800 \mathrm{~S}$ & $8.32 \pm 1.37$ & $336.05 \pm 76.84$ & $344.37 \pm 76.19$ & $2.53 \pm 0.82$ & $97.47 \pm 0.82$ \\
\hline
\end{tabular}


Table 3. Multiple linear regressions between infaunal biomass (carbon) measures, including meiofaunal:macrofaunal $\mathrm{C}$ ratio, and sediment parameters at sites across Chatham Rise, New Zealand (all values $\log _{10}$-transformed). POC: percentage particulate organic matter; $\mathrm{CaCO}_{3}$ : percentage calcium carbonate; chl a: chlorophyll $a$, ng g ${ }^{-1}$ dry sediment

\begin{tabular}{|lrc|}
\hline Variable & $t$ & $\mathrm{p}$ \\
\hline Meiofaunal biomass & & \\
Total regression: $\mathrm{r}^{2}=0.702, F_{2,26}=28.29, \mathrm{p}<0.001$ & -2.07 & 0.49 \\
$\mathrm{POC}$ & 4.31 & $<0.001$ \\
$\mathrm{Chl} a$ & & \\
Macrofaunal biomass & & \\
Total regression: $\mathrm{r}^{2}=0.702, F_{2,26}=28.23, \mathrm{p}<0.001$ & 4.01 & $<0.002$ \\
$\mathrm{CaCO}$ & & $<0.001$ \\
$\mathrm{Chl} a$ & 6.87 & \\
$\mathrm{C} \mathrm{ratio}$ & & \\
Total regression: $\mathrm{r}^{2}=0.400, F_{2,26}=8.01, \mathrm{p}<0.005$ & & \\
$\mathrm{CaCO}$ & -4.00 & $<0.002$ \\
$\mathrm{Chl} a$ & -0.59 & 0.56 \\
\hline
\end{tabular}

1991, Paterson \& Lambshead 1995, Probert et al. 1996, Smith \& Demopoulos 2003).

Total (meio- and macrofaunal) biomass decreased with increasing water depths on both sides of Chatham Rise, but this decline was more pronounced on the northern slope, reflecting different levels of productivity on either side of the crest and the Subtropical Front. Previous Chatham Rise studies across this transect revealed similar biomass patterns, albeit with some differences at deep sites (Nodder et al. 2003, Grove et al. 2006). Encompassing 3 different seasons (austral autumn and spring 1997, summer 2000), meiofaunal biomass was consistently high at the shallow sites and markedly higher on the
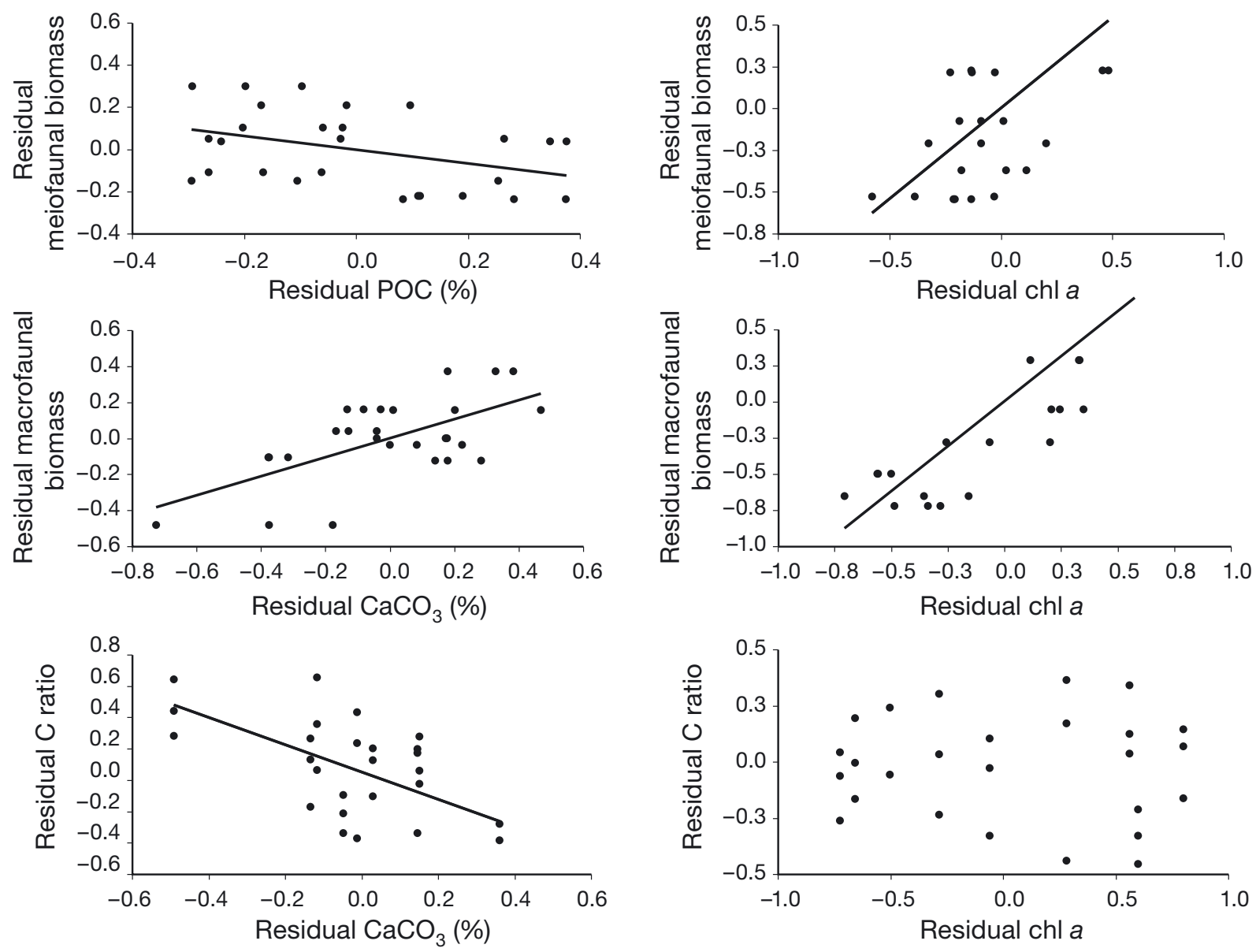

Fig. 5. Partial regression plots of multiple linear regressions between infaunal biomass (carbon) measures, including the meiofaunal:macrofaunal $\mathrm{C}$ ratio and sediment parameters at sites across Chatham Rise, New Zealand (all values $\log _{10}$-transformed). Graphs show the relationship between residuals of each biomass variable versus those of individual predictors. Line of best fit only shown for significant relationships $(\mathrm{p}<0.05)$. POC: particulate organic carbon; $\mathrm{CaCO}_{3}$ : percent calcium carbonate; chl a: chlorophyll $a, \mathrm{ng} \mathrm{g}^{-1}$ dry sediment 
upper southern slope, with maximum values at $450 \mathrm{~S}$ (Grove et al. 2006). Spring biomass values were comparable to those in the present study, ranging from a minimum of $5 \mathrm{mg} \mathrm{C} \mathrm{m}^{-2}$ at $2600 \mathrm{~S}$ (cf. $8 \mathrm{mg} \mathrm{C} \mathrm{m}^{-2}$ at $2800 \mathrm{~S}$, present study) to a maximum of $90 \mathrm{mg} \mathrm{C} \mathrm{m}^{-2}$ at $350 \mathrm{CR}$ (cf. $76 \mathrm{mg} \mathrm{C} \mathrm{m}^{-2}$ at $350 \mathrm{CR}$ ); however, biomass values in summer and autumn were noticeably higher, ranging from 20 to $140 \mathrm{mg} \mathrm{C} \mathrm{m}^{-2}$ and from 40 to $170 \mathrm{mg} \mathrm{C} \mathrm{m}^{-2}$, respectively (Nodder et al. 2003). Macrofaunal biomass (recorded in autumn 1997) was also elevated on the upper slopes, particularly the southern flank, with a maximum at 450S (Nodder et al. 2003). It decreased with increasing water depth on either side, but in contrast to the present study, macrofaunal biomass declined more drastically on the southern side: sites below 1000 m water depth supported considerably lower macrofaunal biomass than sites at equivalent depths on the northern slope, and biomass was at a minimum at the deepest southern site, 2300S. Furthermore, biomass values were generally lower than those reported here, with a maximum of $390 \mathrm{mg} \mathrm{C} \mathrm{m}^{-2}$ at $450 \mathrm{~S}$ (cf. $1168 \mathrm{mg} \mathrm{C} \mathrm{m}^{-2}$ at $750 \mathrm{~S}$, present study), and a minimum of ca. $90 \mathrm{mg} \mathrm{C} \mathrm{m}^{-2}$ at 2300S (Nodder et al. 2003) (cf. $336 \mathrm{mg} \mathrm{C} \mathrm{m}^{-2}$ at $2800 \mathrm{~S})$. The differences in faunal biomass values across seasons and studies are likely related to seasonal (and annual) variation in food supply via surface water productivity and phytodetritus deposition.

The observed biomass patterns suggest enhanced phytodetritus deposition on the southern slope, following phytoplankton blooms in surface waters, similar to the event immediately preceding sample collection in the present study (see Nodder et al. 2007). The extensive spring phytoplankton bloom resulted in elevated surface chl a concentrations (estimated $>2 \mathrm{mg} \mathrm{m}^{-3}$ ) in northern subtropical surface waters, but the deposition of phytodetritus was generally limited to the southern slope, focused at 750S (Nodder et al. 2007). These sites were also characterised by high chl a:total phaeopigment ratios, denoting relatively undegraded phytodetritus within the sediment. Sediment chl a concentration was consistently implicated as influencing benthic biomass across sites, reflecting the availability of labile organic matter that is readily consumed near the sediment-water interface (Richardson \& Young 1987, Witte et al. 2003a).

In addition, comparatively high chl a concentrations within the sediment profile (at 10 to $15 \mathrm{~cm}$ depth) suggest that relatively undegraded phyto-compounds can be buried quickly (e.g. through macrofaunal bioturbation; Witte et al. 2003b), resulting in a pool of labile organic carbon that is available at greater depths and over longer time scales than those immediately associated with episodic flux events (Nodder et al. 2007). The high proportion of high-quality food available at shallow sites and on the southern slope supports consis- tently greater benthic productivity, as evident in higher faunal biomass and sediment community oxygen consumption rates (Probert \& McKnight 1993, Probert et al. 1996, Nodder et al. 2003, 2007, Grove et al. 2006, present study).

A decrease in benthic biomass with decreasing food supply (usually coupled with increasing water depth) is well documented, particularly at deep bathyal and abyssal sites (Snider et al. 1984, Lampitt et al. 1986, Richardson \& Young 1987). As deep-sea benthic communities are greatly dependent on organic matter input from the euphotic zone (Gage \& Tyler 1991, Tyler 2003), the quantity and quality of organic carbon reaching the seafloor influence the abundance and biomass of benthic organisms (Danovaro et al. 1999, Tyler 2003, Ruhl \& Smith 2004, Smith et al. 2009). The findings from the present study support this notion and highlight the close link between (high-quality) organic matter input from surface waters and deep-sea benthic fauna.

In addition to total benthic biomass, there were some differences in relative biomass across Chatham Rise, with a decrease in the relative importance of macrofauna with increasing water depth and decreasing food supply on the northern side. The dominance of macrofauna at shallow sites and the observed shift towards meiofauna with increasing water depth agree with deep-sea studies in other regions that also directly compare different benthic size groups in relation to the partitioning of carbon across a wide depth range (Shirayama 1983, Rowe et al. 1991, 2008, Flach et al. 1999, Galéron et al. 2000). In the western North Atlantic Ocean, meiofaunal biomass (without 'typical' macrofaunal taxa, e.g. polychaetes, amphipods, isopods, tanaids) declined considerably more slowly and became proportionally more important than macrofauna below 1200 m depth (Rowe et al. 1991). Accordingly, the contribution of meiofauna to total faunal biomass increased from $<3 \%$ on the continental shelf ( 70 to $150 \mathrm{~m}$ ) to $10 \%$ at $450 \mathrm{~m}$ and $20 \%$ at $4400 \mathrm{~m}$ depth. At the abyssal site at $5300 \mathrm{~m}$, meiofauna became prevalent, with its biomass $\sim 6$ times greater than that of macrofauna, reflecting $86 \%$ of faunal biomass (Rowe et al. 1991).

Similarly, at 3 tropical Northeast Atlantic sites characterised by different levels of surface water primary productivity (and depths), total benthic biomass was highest at the eutrophic site (1600 to $2100 \mathrm{~m}$ water depth), where meiofauna (i.e. nematodes and copepods only) constituted $12 \%$ of this biomass compared with 56 and $32 \%$ by mega- and macrofauna, respectively (Galéron et al. 2000). At the meso- and oligotrophic sites (3110 and $4640 \mathrm{~m}$ depth), the meiofaunal contribution increased to 27 and $72 \%$ of the total, respectively (without accounting for megafauna). Differences in water depth likely enhanced the effects of different degrees of productivity across sites. Another Northeast 
Atlantic Ocean study of carbon partitioning between macro- and meiofauna revealed similar findings (Flach et al. 1999). On the continental slope of the Goban Spur, meiofaunal biomass (nematodes only) became increasingly important in comparison with macrofauna at water depths between 208 and $4460 \mathrm{~m}$. Following an initial decrease in meiofaunal biomass on the continental shelf to $1000 \mathrm{~m}$ depth, values remained stable, whereas macrofaunal biomass declined drastically between upper slope sites and sites below ca. $1400 \mathrm{~m}$ water depth. The different rates of decline were evident in the ratio of meio- to macrofaunal biomass, which increased with increasing water depth; after an initial decline from ca. 0.12 at the shallowest site to a minimum of ca. 0.02 at $1034 \mathrm{~m}$, it increased to ca. 0.10 at $2182 \mathrm{~m}$ and to ca. 0.37 at $4460 \mathrm{~m}$ water depth (Flach et al. 1999).

These studies highlight the relative shift in importance of meiofaunal biomass with increasing water depth in deep-sea habitats, as observed in the present study. Similarly, this pattern appeared to be determined by a concomitant decrease in food supply, measured as differences in primary productivity (Galéron et al. 2000), carbon input and quality (Flach et al. 1999), or POC flux (Rowe et al. 1991). Food supply, in the form of phytodetritus, was also identified as determining benthic community structure in relation to bathymetry in a global review of biomass patterns in deep-sea benthos (Rex et al. 2006). This analysis of existing data across different regions (but with the Southern Hemisphere under-represented) confirms a general decline in faunal biomass with increasing depth and decreasing organic carbon input across faunal groups. Although macrofaunal biomass was generally higher than that of meiofauna above ca. $2500 \mathrm{~m}$, it was lower below ca. 4000 m, with similar biomasses in-between these depths (Rex et al. 2006).

Chatham Rise deep-sea fauna seems unusual in that the contribution of macrofauna to total biomass did not decline below ca. $80 \%$, and there was no discernible shift towards meiofaunal biomass at the deep southern sites. The more pronounced increase in the relative importance of meiofaunal biomass in the aforementioned studies compared with Chatham Rise benthos may, in part, be related to the greater depth ranges sampled, including abyssal sites. Abyssal sediments are extremely food-deprived, and quantitative estimates of benthic biomass at abyssal sites have revealed the dominance of small-sized organisms (Snider et al. 1984, Richardson \& Young 1987). In the North Pacific Ocean, meiofaunal biomass estimates at $5800 \mathrm{~m}$ water depth were $33 \mathrm{mg}$ wet weight $\mathrm{m}^{-2}$ (excluding foraminiferans), compared with $5.1 \mathrm{mg}$ wet weight $\mathrm{m}^{-2}$ of macrofaunal biomass (Snider et al. 1984). Meiofaunal biomass was also prevalent in the deep Venezuela Basin, Caribbean Sea, where the ratio between meio- and macrofaunal biomass was on average 3.3 (range: 1.2 to 7.1 ) between 3450 and $5050 \mathrm{~m}$ water depth (Richardson \& Young 1987). These biomass comparisons demonstrate clearly that the partitioning of energy is most noticeably skewed towards smaller sized benthos, as food resources diminish greatly with increasing depth into the abyssal realm.

The notable lack of a shift towards meiofaunal biomass at 2800S reflects the influence of other sediment variables affecting biomass patterns in addition to sediment chl a concentration across Chatham Rise. Meiofaunal biomass was negatively related to \%POC, which was highest at $2800 \mathrm{~S}$, and the high value possibly indicates a high proportion of refractory carbon, which may not be directly accessible to benthic fauna. The extremely high C:N molar ratio (108) at this site supports this contention, as it reflects preferential remineralisation of nitrogen over carbon, which, in turn, implies that organic compounds are in forms that are difficult for benthic fauna to assimilate. In contrast, at the deep northern sites, relatively high sediment \%POC was accompanied by C:N values of ca. 9 to 10 . It is, therefore, possible that the low supply of highquality food in the form of sediment chl $a$ at 2800S was exacerbated by high \%POC, further limiting the food supply for meiofauna.

In addition, macrofaunal biomass was positively related to $\% \mathrm{CaCO}_{3}$, which was extremely high at $2800 \mathrm{~S}$ (95.65\%) (and low at the deep northern site, $12.73 \%$ ). The underlying reason for the positive relationship between $\% \mathrm{CaCO}_{3}$ and macrofauna is unclear. Other deep-sea studies have reported positive or negative effects of this variable on meiofauna (Shirayama 1984, Flach et al. 2002, Grove et al. 2006). Positive effects of high $\mathrm{CaCO}_{3}$ content on meiofaunal densities have been linked to this variable being indicative of high food availability (via increased sedimentation) and the provision of large interstitial spaces (Shirayama 1984). In addition, a recent experimental study suggested that the crystallographic structure of sediment particles may influence the distribution and abundance of marine benthic fauna (Cerrano et al. 1999). Manipulation of the proportion of carbonate versus quartz sand within sediment showed significantly lower meio- and macrofaunal colonisation in relation to increasing quartz content, possibly owing to the adverse impact of released silicon-based radicals caused by water movement across quartz crystal surfaces (Cerrano et al. 1999). In view of these studies, sediment conditions other than food supply (i.e. at 2800S) possibly favour some macrofaunal groups and, thereby, profoundly influence Chatham Rise deep-sea assemblages.

While sediment chl a concentration was the single most important sediment variable influencing biomass patterns across Chatham Rise, the exact roles of \% POC 
and $\% \mathrm{CaCO}_{3}$ in relation to benthic assemblages warrant further investigation. The latter includes examination of the possible influence of lateral particle advection on sediment properties at deep-sea sites in the Chatham Rise region. Ongoing data collection in this region focuses on sediment flux dynamics and experimental manipulation of benthic assemblages to elucidate the processes that determine faunal patterns across Chatham Rise.

Acknowledgments. We thank the crew and officers of RV 'Tangaroa', K. Kröger (onboard faunal sieving and sorting), S. Grove (macrofaunal sample processing), L. Northcote (sediment analyses), and D. Leduc (assistance with statistical analysis and Fig. 1). Funding was provided by the New Zealand Foundation for Research, Science and Technology under C01X0027 (Ocean Ecosystems), C01X0501 (Coast \& Oceans OBI), and C01X0702 (Consequences of Earth-Ocean Change).

\section{LITERATURE CITED}

Baguley JG, Montagna PA, Hyde LJ, Kalke RD, Rowe GT (2006) Metazoan meiofauna abundance in relation to environmental variables in the northern Gulf of Mexico deep sea. Deep-Sea Res I 53:1344-1362

Baguley JG, Montagna PA, Hyde LJ, Rowe GT (2008) Metazoan meiofauna biomass, grazing, and weight-dependent respiration in the northern Gulf of Mexico deep sea. DeepSea Res II 55:2607-2616

Bale AJ, Kenny AJ (2005) Sediment analysis and seabed characterisation. In: Eleftheriou A, McIntyre A (eds) Methods for the study of marine benthos. Blackwell, Oxford, p 43-86

Beaulieu SE (2002) Accumulation and fate of phytodetritus on the sea floor. Oceanogr Mar Biol Annu Rev 40:171-232

Billett DSM, Lampitt RS, Rice AL, Mantoura RFC (1983) Seasonal sedimentation of phytoplankton to the deep-sea benthos. Nature 302:520-522

Blair NE, Levin LA, DeMaster DJ, Plaia G (1996) The shortterm fate of fresh algal carbon in continental slope sediments. Limnol Oceanogr 41:1208-1219

Bradford-Grieve JM, Boyd PW, Chang FH, Chiswell S and others (1999) Pelagic ecosystem structure and functioning in the Subtropical Front region east of New Zealand in austral winter and spring 1993. J Plankton Res 21:405-428

Brown B (1991) Biomass of deep-sea benthic communities: polychaetes and other invertebrates. Bull Mar Sci 48: 401-411

Carney RS (1989) Examining relationships between organic carbon flux and deep-sea deposit feeding. In: Bowman MJ, Barber RT, Mooers CNK, Raven JA (eds) Ecology of marine deposit feeders, lecture notes on coastal and estuarine studies. Springer, New York, NY, p 24-58

Cerrano C, Arillo A Bavestrello G, Benatti U, Calcinai B and others (1999) Organism-quartz interactions in structuring benthic communities: towards a marine bio-mineralogy? Ecol Lett 2:1-3

Danovaro R, Dinet A, Duineveld G, Tselepides A (1999) Benthic response to particulate fluxes in different trophic environments: a comparison between the Gulf of LionsCatalan Sea (western-Mediterranean) and the Cretan Sea (eastern-Mediterranean). Prog Oceanogr 44:287-312
Deming J, Carpenter S (2008) Factors influencing benthic bacterial abundance, biomass, and activity on the northern Continental Margin and Deep Basin of the Gulf of Mexico. Deep-Sea Res II 55:2597-2606

Feller RJ, Warwick RM 1988 Energetics. In: Higgins RP, Thiel $\mathrm{H}$ (eds) Introduction to the study of meiofauna. Smithsonian Institution Press, Washington, DC, p 181-196

Flach E, Vanaverbeke J, Heip C (1999) The meiofauna: macrofauna ratio across the continental slope of the Goban Spur (north-east Atlantic). J Mar Biol Assoc UK 79: 233-241

Flach E, Muthumbi A, Heip C (2002) Meiofauna and macrofauna community structure in relation to sediment composition at the Iberian margin compared to the Goban Spur (NE Atlantic). Prog Oceanog 52:433-457

Gage JD, Tyler PA (1991) Deep-sea biology. Cambridge University Press, Cambridge

Galéron J, Sibuet M, Mahaut ML, Dinet A (2000) Variation in structure and biomass of the benthic communities at three contrasting sites in the tropical Northeast Atlantic. Mar Ecol Prog Ser 197:121-137

> Gambi C, Danovaro R (2006) A multiple-scale analysis of metazoan meiofaunal distribution in the deep Mediterranean Sea. Deep-Sea Res I 53:1117-1134

Giere O (2009) Meiobenthology: the microscopic motile fauna of aquatic sediments. Springer, Berlin

> Gooday AJ (2002) Biological responses to seasonally varying fluxes of organic matter to the ocean floor: a review. J Oceanogr 58:305-332

> Gooday AJ, Turley CM (1990) Responses by benthic organisms to inputs of organic material to the ocean floor: a review. Philos Trans R Soc Lond A 331:119-138

Grove SL, Probert PK, Berkenbusch K, Nodder SD (2006) Distribution of bathyal meiofauna in the region of the Subtropical Front, Chatham Rise, south-west Pacific. J Exp Mar Biol Ecol 330:342-355

Jeffrey SW, Mantoura RFC, Wright SW (1997) Phytoplankton pigments in oceanography: guidelines to modern methods. UNESCO Monogr Oceanogr Methodol, Vol 10. UNESCO Publishing, Paris

> Johnson NA, Campbell JW, Moore TS, Rex MA, Etter RJ, McClain CR, Dowell MD (2007) The relationship between the standing stock of deep-sea macrobenthos and surface production in the western North Atlantic. Deep-Sea Res I 54:1350-1360

Jones GA, Kaiteris P (1983) A vacuum gasometric technique for rapid and precise analysis of calcium carbonate in sediments and soils. J Sediment Res 53:655-660

Lampitt RS, Billett DSM, Rice AL (1986) Biomass of the invertebrate megabenthos from 500 to $4100 \mathrm{~m}$ in the northeast Atlantic Ocean. Mar Biol 93:69-81

> Levin LA, Blair NE, Martin CM, DeMaster DJ, Plaia G, Thomas CJ (1999) Macrofaunal processing of phytodetritus at two sites on the Carolina margin: in situ experiments using ${ }^{13} \mathrm{C}$-labeled diatoms. Mar Ecol Prog Ser 182: 37-54

Mackay KA, Wood BA, Clark MR (2005) Chatham Rise bathymetry. Miscellaneous Chart Series 82, National Institute of Water and Atmospheric Research, Wellington

Moodley L, Middelburg JJ, Soetaert K, Boschker HTS, Herman PMJ, Heip CHR (2005) Similar rapid response to phytodetritus deposition in shallow and deep-sea sediments. J Mar Res 63:45-469

> Nodder SD, Northcote LC (2001) Episodic particulate fluxes at southern temperate mid-latitudes $\left(42-45^{\circ} \mathrm{S}\right)$ in the Subtropical Front region, east of New Zealand. Deep-Sea Res I 48:833-864 
Nodder SD, Pilditch CA, Probert PK, Hall JA (2003) Variability in benthic biomass and activity beneath the Subtropical Front, Chatham Rise, south-west Pacific. Deep-Sea Res I 50:959-985

Nodder SD, Duineveld GCA, Pilditch CA, Sutton PJ and others (2007) Focusing of phytodetritus deposition beneath a deep-ocean front, Chatham Rise, New Zealand. Limnol Oceanogr 52:299-314

Pace ML, Knauer GA, Karl DM, Martin JH (1987) Primary production new production, and vertical flux in the eastern Pacific Ocean. Nature 325:803-804

Paterson GLJ, Lambshead PJD (1995) Bathymetric patterns of polychaete diversity in the Rockall Trough, northeast Atlantic. Deep-Sea Res I 42:1199-1214

Pequegnat WE, Gallaway BJ, Pequegnat LH (1990) Aspects of the ecology of the deepwater fauna of the Gulf of Mexico. Am Zool 30:45-64

Pfannkuche O (1993) Benthic response to the sedimentation of particulate organic matter at the BIOTRANS station, $47^{\circ} \mathrm{N}, 20^{\circ} \mathrm{W}$. Deep-Sea Res I 40:135-149

> Probert PK, McKnight DG (1993) Biomass of bathyal macrobenthos in the region of the Subtropical Convergence, Chatham Rise, New Zealand. Deep-Sea Res I 40:1003-1007

Probert PK, Grove SL, McKnight DG, Read GB (1996) Polychaete distribution on the Chatham Rise, southwest Pacific. Int Rev Gesamten Hydrobiol 81:577-588

Quinn GP, Keough MJ (2002) Experimental design and data analysis for biologists. Cambridge University Press, Cambridge

Rex MA, Etter RJ, Morris JS, Crouse J and others (2006) Global bathymetric patterns of standing stock and body size in the deep-sea benthos. Mar Ecol Prog Ser 317:1-8

Richardson MD, Young DK (1987) Abyssal benthos of the Venezuela Basin, Caribbean Sea: standing stock consideration. Deep-Sea Res Part A 34:145-164

Rowe GT (1983) Biomass and production of the deep-sea macrobenthos. In: Rowe G (ed) Deep-sea biology. Wiley Interscience, New York, NY

Rowe GT, Staresinic N (1979) Sources of organic matter to the deep-sea benthos. Ambio Spec Rep 6:19-23

$>$ Rowe GT, Polloni PT, Haedrich RL (1982) The deep-sea macrobenthos on the continental margin of the northwest Atlantic Ocean. Deep-Sea Res Part A 29:257-278

Rowe G, Sibuet M, Deming J, Khripounoff A, Tietjen J, Macko S, Theroux R (1991) 'Total' sediment biomass and preliminary estimates of organic carbon residence time in deep-sea benthos. Mar Ecol Prog Ser 79:99-114

Rowe GT, Wei C, Nunnally C, Haedrich R and others (2008) Comparative biomass structure and estimated carbon flow in food webs in the deep Gulf of Mexico. Deep-Sea Res II 55:2699-2711

Ruhl HA, Smith KL Jr (2004) Shifts in deep-sea community structure linked to climate and food supply. Science 305: $513-515$

Shirayama Y (1983) Size structure of deep-sea meio- and

Editorial responsibility: Paul Snelgrove,

St. John's, Newfoundland, Canada macrobenthos in the western Pacific. Int Rev Gesamten Hydrobiol 68:799-810

Shirayama Y (1984) The abundance of deep sea meiobenthos in the western Pacific in relation to environmental factors. Oceanol Acta 7:113-121

Sibuet $\mathrm{M}$, Albert $\mathrm{P}$, Charmasson S, Deming $\mathrm{J}$ and others (1993) The benthic ecosystem in the three EUMELI sites in the northeast tropical Atlantic: general perspectives and initial results on biological abundance and activities. Ann Inst Oceanogr 69:21-33

Singer JK, Anderson JB, Ledbetter MT, McCave IN, Jones KPN, Wright R (1988) Assessment of analytical techniques for the size analysis of fine-grained sediments. J Sediment Petrol 58:534-543

Smith CR, Demopoulos AWJ (2003) Ecology of the deep Pacific Ocean floor. In: Tyler PA (ed) Ecosystems of the world, Vol 28. Elsevier Science BV, Amsterdam

Smith KL Jr, Ruhl HA, Bett BJ, Billett DSM, Lampitt RS, Kaufmann RS (2009) Climate, carbon cycling, and deep-ocean ecosystems. Proc Natl Acad Sci USA 106:19211-19218

Snider LJ, Burnett BR, Hessler RR (1984) The composition and distribution of meiofauna and nanobiota in a central North Pacific deep-sea area. Deep-Sea Res Part A 31:1225-1249

Soltwedel T (2000) Metazoan meiobenthos along continental margins: a review. Prog Oceanogr 46:59-84

Somerfield PJ, Warwick RM (1996) Meiofauna in marine pollution monitoring programmes: a laboratory manual. Ministry of Agriculture, Fisheries and Food, Lowestoft

> Sutton P (2001) Detailed structure of the Subtropical Front over Chatham Rise, east of New Zealand. J Geophys Res 106:31045-31056

Thiel H (1979) Structural aspects of the deep-sea benthos. Ambio Spec Rep 6:25-31

Tyler PA (ed) (2003) Ecosystems of the deep oceans. In: Goodall DW (ed) Ecosystems of the world, Vol 28. Elsevier Science BV, Amsterdam

Underwood AJ (1997) Experiments in ecology: their logical design and interpretation using analysis of variance. Cambridge University Press, Cambridge

Vanaverbeke J, Soetaert K, Heip C, Vanreusel A (1997) The metazoan meiobenthos along the continental slope of the Goban Spur (NE Atlantic). J Sea Res 38:93-107

> Vanhove S, Vermeeren H, Vanreusel A (2004) Meiofauna towards the South Sandwich Trench (750-6300 m), focus on nematodes. Deep-Sea Res II 51:1665-1687

Witte U, Aberle N, Sand M, Wenzhöfer F (2003a) Rapid response of a deep-sea benthic community to POM enrichment: an in situ experimental study. Mar Ecol Prog Ser 251: $27-36$

Witte U, Wenzhöfer F, Sommer S, Boetius A and others (2003b) In situ experimental evidence of the fate of a phytodetritus pulse at the abyssal sea floor. Nature 424: 763-766

Zar J (1984) Biostatistical analysis. Prentice-Hall, Engelwood Cliffs, NJ

Submitted: September 8, 2010; Accepted: December 23, 2010 Proofs received from author(s): March 6, 2011 